\title{
4 \\ THE HISTORY OF THE ISLAMIC STATE
}

\section{From Abu Musab al-Zarqawi to Abu Bakr al-Baghdadi}

\author{
Brian Fishman
}

The world awoke to the Islamic State on June 29, 2014, when it declared itself the caliphate, a transnational Islamist state led by a single ruler with supposed global authority. Empowered by the Syrian civil war, the Islamic State had just captured Mosul, Iraq's third-largest city. As the Iraqi army melted away, the jihadi militia overran much of Iraq's Sunni Arab northwest and declared a new era in regional and global politics.

The Islamic State's territorial expansion terrified observers around the world and proved deadly for thousands of people in its path. But the Islamic State's geographic expanse was only one aspect of its multifaceted character. Even as the Islamic State built a military and administrative capability for its new caliphate, the group prepared terrorist attacks around the globe and used insurgent tactics to counter an ever-growing list of enemies. The group did not fit neatly into traditional analytical categories: it was a pseudo-state, a terrorist group, and an insurgency simultaneously. This complexity both complicated analysis of the organization's rise and challenged traditional metrics for determining progress and victory in the war against them.

The Islamic State's enemies sought to blunt its appeal to recruits, but disillusioned locals joined it and foreign fighters flowed into Islamic State territory regardless. A variety of motivations drew these recruits, among them a religious passion for jihadi violence, disillusionment with governance and society in their home country, and an apocalyptic vision that the group's claim to be the caliphate was the fulfillment of God's will.

For all of the Islamic State's dramatic growth in 2014, however, many of its core weaknesses were apparent concurrently with its most dramatic successes. The group only sought Sunni Muslims as followers, and its brutality alienated and angered most of its natural constituents. ${ }^{1}$ Rifts between intransigent religious radicals and would-be bureaucrats instigated internal purges and disillusionment. The Islamic State's leaders genuinely believe they have divinely ordained authority to govern and therefore are usually unwilling to create alliances with other groups that do not completely accept their right to lead.

The Islamic State's unwillingness to build sustainable alliances both hardened its enemies and contributed to a slowly crippling resource drain that has furthered its steady decline from the peak of its power in the fall of 2014. Moving forward, the Islamic State's organizational complexity and ideological rigidity offer strength in some respects and weakness in others.

As of 2020, the Islamic State has lost most of its ability to hold and administer wide swaths of territory, but it appears prepared to maintain a capability to disrupt societies in the Middle East and project terrorism globally. Such persistence is unsurprising. In many ways, operating as a terrorist group is the Islamic State's 
natural state. The world awoke to the group in 2014, but the organization-originally under the guise of al-Qaida in Iraq-had declared itself the Islamic State of Iraq in 2006 and went on to conduct a campaign of terrorist violence that made its future gains possible. That past speaks to the group's future: the caliphate is waning, but the Islamic State will remain.

\section{The Islamic State's godfather: Abu Musab al-Zarqawi}

What the world knows as the Islamic State would not exist without Abu Musab al-Zarqawi. Born Ahmad Fadeel al-Khalayleh to a single mother in the dusty Jordanian town of Zarqa, the man who would eventually establish both the organizational underpinning and hyper-violent ethos of the Islamic State did not show early signs of a future in Islamist militancy. ${ }^{2}$

Instead, he was a petty criminal. ${ }^{3}$ As a teenager, al-Zarqawi smoked, drank, and worked in a video store. ${ }^{4}$ To counter his life of crime, al-Zarqawi's mother urged him to embrace religion, and he eventually did so with a zealot's lust, ultimately using a razor to meticulously scrape a tattoo from his forearm. ${ }^{5}$

The Soviet Union invaded Afghanistan in 1979, setting off a decade-long war that attracted Muslim fighters from around the world during the 1980s. Al-Zarqawi eventually joined the fight, but he waited until 1989 as the Soviets withdrew and the war increasingly devolved into an internecine battle among various Afghan factions. ${ }^{6}$

Al-Qaida sputtered to life in 1988 as an effort to keep united the foreign fighters who had joined the Afghan resistance. Nonetheless, most foreigners drifted home to normal lives once the Soviets withdrew. As those fighters departed, al-Zarqawi arrived. Although he reputedly participated in some battles among the various resistance factions on his first trip to Afghanistan, little is known in detail. ${ }^{7}$

Al-Zarqawi and hardline jihadi scholar Abu Muhammad al-Maqdisi, also a Jordanian, journeyed back to Jordan and founded a short-lived jihadi group known as Bayt al-Imam in 1993, but they were quickly arrested and imprisoned. ${ }^{8}$

The jihadi prisoners in al-Jafr prison initially selected al-Maqdisi as their amir (leader) because of his reputation as a scholar, but al-Maqdisi's powerful prose and intellect did not translate into natural leadership skills. ${ }^{9}$ For example, the jihadis soured on al-Maqdisi's unwillingness to challenge the prison guards; al-Zarqawi, on the other hand, preened "like a peacock" and challenged the guards repeatedly, resulting in beatings that only bolstered his credibility with other prisoners. ${ }^{10}$ Before long, the jihadi prisoners replaced al-Maqdisi with al-Zarqawi as amir. ${ }^{11}$

After al-Zarqawi's release from prison, he aimed to join the jihad in Chechnya, where international fighters flocked to oppose Russian dominance over a predominately Muslim population. To reach Chechnya, al-Zarqawi needed money and connections, which could be acquired in South Asia. Along with two friends, al-Zarqawi arrived in Kandahar, Afghanistan, in December 1999. ${ }^{12}$

Al-Zarqawi arrived at a perfect time to strike a deal with al-Qaida, primarily because of intra-jihadi politics. Al-Qaida was the leading jihadi organization among 13 other jihadi groups in Afghanistan. ${ }^{13}$ Many allied with al-Qaida, but some disagreed on strategy. In 1998, al-Qaida embraced a strategy focused on attacking the United States, but most jihadis prioritized striking governments in predominately Muslim regions of the world. ${ }^{14}$ Both sides of the debate aimed to overthrow local governments, but al-Qaida chief Usama bin Ladin argued that it was too difficult to overthrow Muslim rulers if they were supported by the United States. ${ }^{15}$ Bin Ladin's goal was to keep striking the United States with terrorist attacks until Washington ended its support to local governments that were in al-Qaida's crosshairs. ${ }^{16}$ Once Muslim governments lost U.S. support, then it would be al-Qaida's time to seek revolution. ${ }^{17}$

$\mathrm{Al}-$ Zarqawi was both ideologically radical and favored direct strikes on near enemies. ${ }^{18} \mathrm{Al}-\mathrm{Q}$ aida valued long-term strategic planning, while al-Zarqawi relied on instinct to survive and thrive. Al-Zarqawi sided with jihadis who believed the Taliban were illegitimate ${ }^{19}$ because they accepted "un-Islamic" Afghan cultural practices, such as decorating the graves of ancestors. Al-Zarqawi also disagreed with al-Qaida's focus 
on the United States. He hated the United States, but he wanted to attack hard and soon, which meant focusing on the closer targets of governments in the region. These disagreements would return years later.

Despite his immediate distaste for al-Zarqawi, Bin Ladin ultimately offered the younger jihadi training and start-up funds. ${ }^{20} \mathrm{Al}$-Zarqawi set up camp outside the western Afghan city of Herat, not far from the Iranian border. ${ }^{21} \mathrm{Al}$-Zarqawi recruited widely among Jordanian, Palestinian, and Syrian fighters, many of whom brought their families with them to Afghanistan. In a decade, he had transformed from a forgettable, low-level foot soldier into a leader.

After the 9/11 attacks, al-Zarqawi immediately fled to Kandahar, which was the center of the Taliban resistance to the U.S. counterattack after 9/11. Ultimately, Taliban chief Mullah Omar ordered his supporters to retreat from Kandahar. ${ }^{22}$ Like many others, al-Zarqawi then slipped out of Afghanistan to seek safety in Iran. ${ }^{23}$ Yet he already had his eyes fixed on the next big prize: Iraq.

\section{The Islamic State's predecessor: al-Qaida in Iraq}

Al-Zarqawi crossed into northern Iraq in mid-2002, where he was welcomed by a primarily Kurdish jihadi group called Ansar al-Islam. ${ }^{24}$ Al-Zarqawi hoped to confront a U.S. invasion of Iraq violently, but he was not content to wait for that moment. Using a broad network of Levantine jihadis, al-Zarqawi built the framework for a regional terrorist organization before a shot was fired in Iraq. Indeed, the Islamic State's "Godfather" fired first at the United States in Jordan. On October 28, 2002, gunmen in Amman assassinated Laurence Foley, an American diplomat with the Agency for International Development, an operation funded by al-Zarqawi. ${ }^{25}$

The U.S.-led coalition invaded Iraq on March 20, 2003, with a series of devastating strikes against Ansar al-Islam's jihadi camps in Iraqi Kurdistan. ${ }^{26}$ Cruise missiles rained down, and U.S. Special Operations Forces killed and captured survivors. ${ }^{27}$ Kurdish and jihadi survivors fled in all directions, including across the border into northern Iran. ${ }^{28}$

Al-Zarqawi was already ensconced in Baghdad when the invasion began. ${ }^{29} \mathrm{He}$ was joined by a range of foreign jihadis, many of whom had arrived in Iraq on buses from the Syrian cities of Damascus and Aleppo. Perhaps the most important, however, was an Egyptian known as Abu Ayyub al-Masri, who would take the nom de guerre Abu Hamza al-Muhajir. Al-Masri had a history of working with Egyptian jihadi groups as a bombmaker, but he was an ideological extremist like al-Zarqawi and would eventually become one of the most important figures in Islamic State history.

The foreign jihadis quickly built ties with officials from Saddam Hussein's regime who undergirded the early stages of the Iraqi insurgency. Saddam had delegated planning for the resistance to a senior general named Izzat al-Douri, who aimed to broaden resistance to the U.S.-led invasion by enabling groups with a wide variety of ideological dispositions. Some of the early insurgent groups in Iraq were secular Baathist nationalists, others embraced a Muslim Brotherhood-like Islamism, and others reflected the jihadi disposition of foreigners like al-Zarqawi.

Prior to the U.S.-led invasion, al-Douri had led Saddam's "Faith Campaign," which worked to reconfigure Iraq's traditional secularism into an "Iraqi Islam." ${ }^{30}$ Saddam hoped this would both mitigate Iranian influence among Iraq's Shia population and staunch the influence of foreign Muslim Brotherhood and Salafis among Iraq's Sunnis. ${ }^{31}$ This history meant al-Douri was theoretically well positioned to co-opt extremism in the insurgency. In the end, however, it did not work. Although the Baathists served as the backbone of the early insurgency, the most diehard fighters were eventually co-opted by the foreign jihadis.

Al-Zarqawi's first major attack in Iraq embodied the early collaboration between Baathists and foreign jihadis. On August 7, 2003, a truck bomb exploded at the Jordanian Embassy in Baghdad. ${ }^{32}$ Two weeks later, a similar bomb exploded at the United Nations headquarters in Baghdad. ${ }^{33}$ Al-Zarqawi's allies, in conjunction with former Iraqi officers, organized both attacks. While the attacks served both Baathist and jihadi goals, al-Zarqawi's movement ultimately claimed the strikes and gained the most attention. 
Al-Zarqawi's most important attack early in the insurgency came later in 2003 when he sent his father-inlaw on a suicide mission to kill the prominent Shia cleric Ayatollah Muhammad Bakir al-Hakim in Najaf. ${ }^{34}$ After the U.S. invasion, al-Hakim had returned to Iraq from exile in Iran and advocated productive engagement with U.S. forces. The attack both killed a potentially unifying figure in Iraq's Shia community and illustrated the strategy of sectarian war that would come to be al-Zarqawi and the Islamic State's calling card.

Al-Zarqawi's penchant for brutality and sectarianism disturbed al-Qaida's leadership. Throughout 2003, al-Zarqawi communicated via messenger with al-Qaida's leaders, who argued against a strategy of unremitting attacks on Iraqi Shia. ${ }^{35}$ Ideologically, al-Qaida argued that everyday Shia were lapsed Muslims who should be reformed, not killed. Al-Qaida agreed that the jihadis would eventually need to confront organized Shia groups, including Iran, but they hoped first to win over everyday Shia and worried that brutally killing Shia would alienate less radical Sunnis.

Practically, al-Qaida's leaders also worried that many al-Qaida leaders lived in Iran and, though they were sometimes able to communicate externally during this period, were also under house arrest-style restrictions and could be killed or traded by the regime if push came to shove.

Despite the early attacks, the leadership council of al-Zarqawi's group, Jamaat al-Tawhid wal-Jihad, was upset when they gathered in early 2004. They had conducted many attacks but made few tangible gains. To change that, the group pledged to seize territory and confront the United States and the Iraqi Security Forces directly.

The location for this showdown was Fallujah, a city of 200,000 people 80 miles up the Euphrates River from Baghdad. The city had a long reputation for religious conservatism, and it was there that a collection of militant groups, including al-Zarqawi's Jamaat al-Tawhid wal-Jihad, asserted absolute control. ${ }^{36}$ After this militant coalition repelled an initial attack by U.S. troops in April 2004, al-Zarqawi's legend ballooned.

Al-Zarqawi seized that moment to close his longstanding negotiations with al-Qaida. Despite their strategic disagreements, al-Zarqawi publicly pledged allegiance to Bin Ladin in October 2004 and thereby created a new entity called al-Qaida in Iraq (AQI). ${ }^{37}$

Al-Zarqawi praised the al-Qaida leader and stated his willingness to follow orders, although he explained that he was swearing allegiance only after al-Qaida "came to understand our approach, and their hearts warmed to it." ${ }^{38}$ In reality, however, future discord between al-Qaida diehards and al-Zarqawi's intellectual descendants suggest the differences between al-Zarqawi and al-Qaida were never fully resolved.

In November 2004, U.S. forces successfully pushed the jihadi-led coalition of insurgents out of Fallujah. A seminal moment, however, occurred in the interim: al-Zarqawi had joined al-Qaida and became the undisputed leading figure among foreign jihadis in Iraq. Moreover, the jihadis had a taste of what it meant to control territory. They had established the precedent that would eventually be reflected as true jihadi governance in the future Islamic State.

AQI conducted many atrocities while in control of Fallujah. One was particularly public. On a grainy video distributed globally online, al-Zarqawi personally beheaded a captured American businessman named Nicholas Berg. The video displayed Berg dressed in an orange jumpsuit like those worn by American prisoners at Guantanamo Bay. After making a brief statement reiterating jihadi goals, al-Zarqawi beheaded the victim. ${ }^{39}$ Ten years later, Islamic State beheadings would loyally follow this basic script.

The video also reflected new modes of propaganda distribution. Capitalizing on newly available broadband technology, which increased the size of a file that could be placed online, duplicate copies of the video were uploaded across the internet. The numerous links to these sites were subsequently distributed in messages on dedicated jihadi web forums.

Even as al-Zarqawi planted the jihadi flag in Fallujah, he and Sayf al-Adl, a prominent al-Qaida operative who managed al-Zarqawi's ties to the network, aimed to develop a shared vision for the newly created AQI. This was no easy task: they needed to shape al-Zarqawi's brutality into a framework that al-Qaida's leaders recognized as strategy rather than nihilism. The result was a seven-stage plan for taking over the world by $2020 .^{40}$ 
The plan aimed to extend the fighting in Iraq and discredit the governments of Muslim-majority countries by forcing them to endorse the U.S. invasion. Over the long run, the plan sought to establish an Islamic State, but it looked to do so not in Iraq but in Syria. Stage five of the plan indicated that the caliphate would be re-established in Syria between 2013 and 2016, a prediction that turned out to be accurate; the Islamic State declared itself the caliphate in $2014 .{ }^{41}$

The precision of that prediction was luck more than calculated strategy, but the so-called "master plan" was revelatory in identifying why Syria, not Iraq, was the best locale for reestablishing the caliphate. Most important were demographics. Iraq's population is $60 \%$ Shia, and only about $20 \%$ of the population are Sunni Arabs. Syria, on the other hand, is 70\% Sunni Arab and was governed by Bashar al-Assad, who came from a small offshoot sect of Shia Islam known as Alawites.

The world awoke to the Islamic State in 2014, but a decade earlier, Sayf al-Adl and the "Zarqawists" recognized that even as they fought in Baghdad, their long-term path to geopolitical power ran through Damascus, Aleppo, and Raqqa.

\section{Tensions increase between al-Zarqawi and al-Qaida}

Al-Zarqawi's decision to formally join al-Qaida represented the high point of cooperation between the two movements, but this marriage was never built to last. As 2005 wore on, al-Qaida's leadership grew increasingly frustrated with al-Zarqawi's growing reputation for brutality. ${ }^{42} \mathrm{Al}-Z$ awahiri also questioned whether Iraqis would be more amenable to have an Iraqi leading jihadi forces in the country.

Al-Zawahiri, and al-Qaida generally, maintained that the jihadi movement would eventually need to win over the Muslim masses globally to assert political power. Al-Zarqawi disagreed with that notion. Whereas al-Qaida's leadership felt that Sunni Muslims needed to be led back to what they considered the truth path of Islam, al-Zarqawi was more inclined to simply write off intransigent Sunnis—and kill them. For al-Zarqawi, publicizing brutal killings was not just a way to spread fear, but he believed that Muslims who rejected that violence revealed themselves as apostates.

The breakdown occurred in November 2005 when suicide bombers dispatched by al-Zarqawi detonated explosives inside Western-branded hotels in the Jordanian capital of Amman. One bomb exploded in the middle of a wedding celebration, killing dozens. ${ }^{43}$ Al-Zarqawi initially hailed the attacks as a blow against a key American ally in the region, but the Jordanian public was aghast. As with most of al-Zarqawi's attacks, the vast majority of victims were Muslim. Al-Qaida was furious.

Al-Qaida's response to al-Zarqawi's intransigence was swift. Multiple senior officials sent alZarqawi letters urging him to limit the violence. ${ }^{44}$ In January 2006, al-Qaida dispatched one of its most senior commanders, Abd al-Hadi al-Iraqi, from Pakistan to Iraq on a mission to muzzle the young Jordanian. ${ }^{45}$

Al-Zarqawi must have understood the frustration and took some steps to manage it. In January 2006, AQI announced that it would begin operating within an umbrella group called the Mujahidin Shura Council, which ostensibly would be led by an Iraqi and endeavored to present itself as a vehicle for Iraqfocused militant groups. ${ }^{46}$ One of those organizations was a small, highly sectarian group that operated primarily in Iraqi's Diyala Province. Its religious leader was a young man named Ibrahim Awad Ibrahim al-Badri, who would eventually become infamous as Abu Bakr al-Baghdadi, supposed caliph and leader of the Islamic State.

Al-Baghdadi's day in the limelight was still far off, but the jihadi environment in Iraq was shifting dramatically. On February 22, 2006, a team of jihadis broke into the al-Askariyya Mosque in Samarra and wired the entire shrine with explosives. The shrine is considered the third-holiest site for Shia Muslims in Iraq and was known globally for its shimmering gold-tiled dome. No one was killed by the bomb blast itself, but the explosion devastated the building — and precipitated an unprecedented sectarian backlash by Shia militias. ${ }^{47}$ Consistent with al-Qaida's guidance, al-Zarqawi and AQI did not claim credit for the attack, 
but his aim was achieved regardless. Al-Zarqawi had been trying for years to provoke an all-out sectarian war in Iraq. After the al-Askariyya Mosque bombing, he got it.

Al-Zarqawi did not have long to celebrate this achievement. On June 8, 2006, a U.S. Special Operations Command Task Force tracked one of al-Zarqawi's clerical advisors to a safehouse west of Baquba. ${ }^{48}$ Watching the scene via real-time drone footage, analysts caught sight of a man who looked like al-Zarqawi, and commanders approved an airstrike on the safe house. Al-Zarqawi rushed out of the safe house just before two 500-pound bombs plunged into it, but the blast was devastating. American Special Operations Forces were on the ground at the safe house in time to watch al-Zarqawi die. ${ }^{49}$

Al-Zarqawi's death was a dramatic blow to the jihadi movement in Iraq, but it was not a death knell. AlZarqawi's supporters even celebrated his martyrdom, claiming that images of his body revealed that he was smiling in death. Al-Zarqawi was no longer a commander, but he would continue to inspire a generation of jihadis. His replacement was no legend, but he was a capable militant. Abu Ayyub al-Masri had joined al-Zarqawi prior to the U.S. invasion. He kept the AQI military machine humming, but as the summer of 2006 wore on, he faced an extraordinary political challenge: American troops began to experiment with counterinsurgency techniques designed to win over the Sunni population in western Iraq.

Many Sunni tribal leaders were tired of AQI's draconian proclamations and unremitting violence, and the outbreak of full-on sectarian war left them vulnerable. Al-Zarqawi's strategy had been to provoke Shia attacks on Sunnis to push those Sunnis into the arms of AQI. The strategy, however, was too clever; the Sunni tribal leaders were looking for someone to defend them against the empowered Shia militias, but many turned to the U.S. military rather than AQI for that security.

\section{The formation of the Islamic State of Iraq}

In September 2006, the first coalition of Sunni tribal leaders formally announced their opposition to AQI. For al-Masri, this must have been a severe crisis. AQI had created a sectarian war, but it was not reaping the political and strategic benefits.

On October 15, 2006, al-Masri moved dramatically to rectify the problem. Without informing alQaida, the Mujahidin Shura Council announced that it was dissolving, and instead it would establish the Islamic State of Iraq (ISI). The ISI would be a true Islamic state designed to govern and build the foundation of a caliphate. ${ }^{50}$ The new "state" quickly announced a government structure with ministries—ranging from "War" to "Fisheries"-led by the equivalent of cabinet officials. It described leadership succession procedures and explained in detail the state's obligations to its "citizens."

Yet even as the ISI moved to collect garbage and manage low-level public works projects, it made clear that imposing its understanding of Islamic law took priority. If there was ever a tradeoff between imposing divine punishments and bettering people's lives, the state declared that "improving their conditions is less important than the condition of their religion." 51

The ISI's close supporters embraced it, but the new state did not gain wide currency among Muslims. Indeed, even most jihadis declared the group illegitimate. The jihadis complained about a range of issues: the ISI did not actually control that much territory, which many jihadis thought was necessary for an Islamic state to be valid, and the group could not even rally most Muslims in Iraq to its side. The ISI responded that territory was not critical and described a feudal system of government in which local leaders swore allegiance to the ISI's amir and would govern whatever territory they could. They pointed to the Prophet Muhammad's first "state" as a reference point because it had also been quite weak compared to its enemies.

In the end, the most important criticism of the ISI was its choice of amir. The man was largely unknown, which raised tremendous alarm among jihadis globally. His name was Hamid Dawud Khalil al-Zawi, but he was known as Abu Omar al-Baghdadi. Prior to declaring the ISI, the Zarqawist movement in Iraq had explored the qualifications required of a future amir and potential caliph. Among relatively standard 
leadership qualities, they pointed to one very specific characteristic: anyone selected as amir must be a direct descendent of the Prophet Muhammad's tribe of Quraysh. ${ }^{52}$

Across the Middle East, many people claim to descend from Quraysh, but the criteria excluded many logical candidates in Iraq, including al-Masri. Abu Omar, on the other hand, fit the bill. He was Iraqi and had briefly served within the Baathist state as part of the security services. Abu Omar was purged from the Iraqi state because of his extreme Salafi views and, according to jihadi biographies, served as a mechanic and a small-time preacher during Saddam's reign. ${ }^{53}$

Jihadis outside of Iraq had never heard of him. Al-Qaida's leaders had not been forewarned that AQI was going to declare an Islamic state or given an opportunity to opine about the leader of the new institution. After Abu Omar's appointment, al-Qaida's leadership repeatedly pressed its partners in Iraq for information on the new amir. To complicate matters, the ISI went to great lengths to keep Abu Omar's true identity a mystery. ${ }^{54}$ The deception was effective; a disillusioned defector from the ISI arrived in Pakistan to brief al-Qaida and claimed that Abu Omar was a fabricated persona and not a real person. American interrogators heard the same story — and repeated it publicly—after capturing the ISI's media chief in $2007 .^{55}$

The ISI's trickery reflected unique and careful operational security measures, but their disregard for alQaida was more important. After its establishment, the ISI clearly declared that al-Qaida no longer existed in Iraq. It was not until 2007-a year after the group's declaration-that al-Qaida's leadership publicly agreed. Despite this messaging, however, there clearly was still engagement between the two groups, which was notable in the alignment between their political statements in late 2007. Al-Qaida's leadership later claimed that the ISI continued to operate as one of its affiliates despite the public disavowal. Whatever the backroom deals, the ambiguity was real for many of the groups' supporters, and both sides would tell their own versions of this history when the two groups ultimately split violently in 2013.

Despite its bold claims, the ISI went into headlong retreat shortly after announcing the establishment of the so-called state. By the spring of 2007, it was clear that the declaration—far from being a triumph—was turning into a disaster. As Sunni tribal groups rebelled and U.S. troops flowed into Iraq, the ISI was losing. Even then, however, the group's long-term vision and persistent commitment to its vision were clear. In April 2007, Abu Omar described the group's intent to "remain," a concept that is still a core element of the Islamic State's rhetoric today.

Over the following three years, the ISI was battered and bruised by U.S. troops, Sunni militias, and the Iraqi government. When al-Masri announced the state in October 2006, he claimed to have 12,000 men under arms and another 12,000 waiting in the wings. ${ }^{56}$ By 2011, the U.S. military estimated that their numbers were down to about $1,000 .{ }^{57}$ Despite these setbacks, however, the ISI's commitment to "remain" was not just talk; the group modified its structure and operational model and survived despite massive losses.

The group survived by evolving from an insurgent movement that held territory to a terrorist group that operated underground. It reduced attacks against U.S. forces but assassinated Sunni leaders who had opposed it and conducted bombings and hit-and-run attacks against Iraqi troops. Iraq's Anbar Province had been al-Zarqawi's most important stronghold early in the war, but the ISI withdrew most of its surviving forces to Ninawa Province and the city of Mosul, in Iraq's far north. Mosul had several advantages: the U.S. surge never reached Mosul, and it was close to the group's support networks across the border in Syria, where a trickle of foreign fighters still entered Iraq even at the group's weakest point.

Throughout this period, the ISI laid the groundwork for resurrection. It operated like a criminal mafia to raise money and maintained a strict organizational structure that gathered intelligence and spread propaganda. The group's media apparatus was not as active as during the group's high point, but it continued to release statements and videos of attacks. Indeed, the ISI remained a very potent terrorist organization during this period of decline: there were more suicide bombings in Iraq between 2008 and 2010 than in any other country in the world. ${ }^{58}$ The U.S. surge damaged the ISI significantly, but it was never defeated. 
The U.S. military did not see it that way at the time. In early 2010, American and Iraqi troops surrounded and killed both Abu Omar al-Baghdadi and al-Masri, al-Zarqawi's immediate successor and the ISI's minister of war. That spring, many of the group's top leaders were killed or captured. This was a tremendous success for counterterrorism officials, and to many of them, it looked like the military defeat of the ISI. They were wrong.

\section{The ISI returns with a vengeance: Abu Bakr al-Baghdadi takes the helm}

The ISI's leadership was devastated in the spring of 2010, but the group's position in Iraq strengthened in other ways. The United States had agreed to withdraw from Iraq by the end of 2010 per a Status of Forces Agreement signed by President George W. Bush, and the Obama administration failed to negotiate a new agreement that may have left a residual U.S. force in the country. As troops prepared to leave Iraq, they were less active in pursuing ISI operatives.

Meanwhile, Sunni frustration with the Iraqi government grew. As a primarily Shia country, the Iraqi government was generally led by Shia religious parties, some of which had close ties to Iran. Many Sunnis resented the government in Baghdad and complained that it aggressively targeted Sunni tribal and political leadership. The tension rose as tribal groups that once sought partnership with the United States to ensure their security had to fend for themselves. As the Iraqi government began to look like more of a threat to Sunni leaders than the weakened ISI, some turned to the jihadi group to push back on Baghdad. Al-Zarqawi was long dead, but to a limited extent, the strategic vision he sketched in 2004 started to become a reality.

Despite the shifting political sands in Iraq, the ISI did not have a smooth path back to power. A core problem was replacing Abu Omar al-Baghdadi as amir. Back in 2006, the ISI described three legitimate processes for selecting an amir: the previous amir could select a successor, leading figures in the state could choose a new leader by consensus, or, in worst-case scenarios, a new leader could assert control by force. Unlike the selection of al-Masri as al-Zarqawi's successor, which took days, selecting the replacement for Abu Omar took weeks. This suggests that Abu Omar's successor seems to have been chosen via some combination of the latter two methods.

Like Abu Omar al-Baghdadi, Abu Bakr al-Baghdadi was unknown outside Iraq. He had been raised in Samarra, north of Baghdad, in a prominent tribal family, and received a $\mathrm{PhD}$ in Islamic history. ${ }^{59} \mathrm{Abu} \mathrm{Bakr}$ joined the Iraqi insurgency in the early years and quickly became a follower of al-Zarqawi.

Abu Bakr had been imprisoned for his support of the insurgency, where he gained a reputation among guards as a skilled negotiator between various factions in the prison yard and among prisoners as an ideological extremist. After his release from prison, Abu Bakr returned to the insurgency and eventually served as the ISI's governor in Mosul when it was the group's center of gravity after the U.S. troop surge. ${ }^{60}$ Like Abu Omar, Abu Bakr was unknown to the international jihadi community, but his stronger resume as a scholar, militant, and manager was perfect for the leadership role.

Abu Bakr was named amir of the ISI on May 16, 2010. ${ }^{61}$ His organization was battered, but he quickly seized on the political climate in Iraq. Abu Bakr rebuilt relationships with Sunni tribes and embraced former Saddam-era military officials. The world had stopped paying close attention to Iraq, but the largescale car bombs in Baghdad had resumed, and the rate of foreign fighters entering Iraq ticked up. The ISI targeted banks, government ministries, and key officials. The group also began a series of prison breaks, which served to bolster its ranks. The ISI was no longer a territorial entity as it had been in 2006, but as Abu Bakr stepped into command, it was a highly effective terrorist organization. ${ }^{62}$

Even as the ISI strengthened in Iraq, there was a surge of optimism across the Middle East about the prospect of democratic revolution. In Tunisia, Egypt, Libya, and Bahrain, protest movements exploded against their autocratic regimes. Known colloquially as the Arab Spring, it was a halcyon moment full of hope for everyone in the region. Inevitably, that revolution arrived in the ISI's backyard: not in Iraq but in Syria. 
In February 2011, Syrian authorities arrested a group of young boys for scrawling a slogan from the Egyptian Arab Spring movement - "the people want to topple the regime"- on a wall in the southern town of Deraa. When the community erupted to protest their arrest, regime snipers opened fire. The violence was returned almost immediately and the slow, inexorable slide toward a Syrian civil war began.

The ISI quickly took notice. In April 2011, an ISI shura council member released a statement that noted "the good news about the Muslim people in some Syrian cities starting to mobilize" and pledged the ISI's "support." ${ }^{33}$ In the ISI's lexicon, "support" had only one meaning: the ISI was coming to Syria, and not just to protest but to fight.

Indeed, the ISI had longstanding networks in Syria that had previously been used to funnel fighters in and out of Iraq, but many of those were known to the Syrian regime, which had enabled jihadi logistics networks for moving fighters into Iraq. Yet now the tactical accommodation between jihadis and the Syrian regime was breaking down. In response, Abu Bakr sent a Syrian deputy named Abu Muhammad alJolani to serve as his primary delegate in Syria in August 2011. ${ }^{64}$

Al-Jolani quickly gained legitimacy with a wide range of Syrian militants who had emerged to fight the Syrian regime. Unlike al-Baghdadi and the Zarqawists around him, al-Jolani took a constructive approach to other Islamist militant groups. He did not demand their immediate allegiance and instead thought that a cooperative relationship with other militants was prudent. Al-Jolani's group in Syria did not initially acknowledge its ties to the ISI, but it soon announced itself as Jabhat al-Nusra (or the Nusra Front) in January 2012. ${ }^{65}$

The Nusra Front's ideological vision for an Islamic state contradicted the secular objectives of many early Syrian revolutionaries. Yet Syrian militants also welcomed experienced fighters who could strike the Syrian regime and were willing to overlook the group's ideological extremism in exchange for tactical victories. At the same time, the Syrian regime conducted false flag attacks and released jihadis and Islamists from prisons to bolster its claim that the rebellion was dominated by jihadis - an attempt to weaken international support for the rebels. ${ }^{66}$

Sunni states in the region-Saudi Arabia, Qatar, and the United Arab Emirates-sponsored militants who worked closely with Nusra and perhaps the group itself. The regional powers did not have good options for militants to support. They wanted to overthrow the Iranian-backed regime in Damascus to counter Iranian influence, but the secular and nationalist elements of the Free Syrian Army rebel coalition were not nearly as effective as the various Islamist militants.

Even the United States was slow to draw a direct link between the ISI and the Nusra Front in Syria. The U.S. State Department did not formally link Nusra to the ISI and its forefather AQI until December 2012, nearly 18 months after it first appeared in Syria and almost a year after it formally announced itself. ${ }^{67}$

The Supreme Joint Military Council, an umbrella movement for Syrian rebel groups, swiftly denounced the State Department's designation and rejected the suggestion of "extremist forces" in Syria. The Nusra Front, however, was bolstered both by the Syrian regime and many of the Syrian revolutionaries opposed to it. Both factions would eventually regret their decisions to do so.

Despite the Nusra Front's manifest ties to the ISI, many observers of the early Syrian civil war did not recognize the link. Two potential reasons stand out. First, the ISI was erroneously believed to be defunct because of the defeats it suffered between 2007 and 2010. Second, observers were rightfully critical of the al-Assad regime in Syria and believed in the righteousness of the rebellion against it. Acknowledging that jihadis had infiltrated the rebellion seemed to fall directly into the political trap that al-Assad hoped to set to discredit it.

\section{The Islamic State in Iraq and Syria}

In April 2013, the ISI removed any doubt about the Nusra Front's origins. Abu Bakr reportedly ordered al-Jolani to attack secular Syrian rebel groups or be dissolved. Al-Jolani ignored the directive. On April 9, 
2013, the ISI announced the "abolition of both names, the Islamic State of Iraq and Jabhat al-Nusra, and we merge them under one name: the Islamic State in Iraq and al-Sham (ISIS)." ${ }^{68}$

The merger was a nonstarter for al-Jolani. The next day he acknowledged the ISI's initial support but rejected the merger and announced that he would only take orders from Ayman al-Zawahiri, the leader of al-Qaida, not Abu Bakr and the ISIS leadership in Iraq. The discord between al-Jolani and Abu Bakr revealed a deeper and longer-standing tension between the ISI and al-Qaida. When Bin Ladin was killed in May 2011, al-Zawahiri assumed leadership of al-Qaida. Al-Zawahiri was a longstanding jihadi in good standing but did not command the same respect among jihadis globally as Bin Ladin — and he did not have the ability to rein in Abu Bakr as an increasingly independent leader. The tripartite conflict played out publicly, as well as through a series of private letters between the al-Qaida leadership and the ISI. The dispute spanned years of intra-jihadi politics. Al-Jolani acknowledged the Nusra Front's origins in the ISI but asserted that Nusra was a direct affiliate of al-Qaida, on par with ISIS. Al-Zawahiri agreed with this assessment and asserted that he therefore had the authority to mediate the dispute between Abu Bakr and al-Jolani. Abu Bakr not only rejected that formulation as guidance for 2013, but he argued that when the ISI was established in 2006, it had formally separated from al-Qaida. From Abu Bakr's perspective, the implications of this history were two-fold: both that Nusra Front was exclusively a product of the ISI and that al-Zawahiri had no authority to mediate the dispute with al-Jolani. ${ }^{69}$

It is hard to know the exact sequence of events. On the one hand, al-Qaida publicly acknowledged the ISI's independence in 2007, but that statement seems to have been coordinated with the ISI leadership at the time to bolster the former's legitimacy. Meanwhile, al-Zawahiri subsequently asserted that Abu Bakr had secretly sworn allegiance to al-Qaida. He produced letters suggesting that al-Qaida leaders believed this to be true but did not show a record of the actual pledge. The ISI's most important decisions were made without input from al-Qaida, most notably the decision to declare the "state" in the first place and the selection of both Abu Omar and Abu Bakr. Whether it had secretly sworn allegiance to al-Qaida's leadership or not, the ISI operated independently from the time of its original announcement. ${ }^{70}$

In 2013, the dispute grew more heated and eventually devolved into open warfare between ISIS and al-Qaida, including the Nusra Front. Al-Zawahiri publicly denounced both al-Jolani and Abu Bakr for airing their grievances publicly, but he basically accepted al-Jolani's position that the two organizations were peers. In doing so, al-Zawahiri asserted al-Qaida's institutional authority over both groups, but he also was backing al-Jolani's strategic approach.

Abu Bakr had a Zarqawist insistence that other groups fall in line behind his leadership- - he genuinely saw ISIS as the locus for a future caliphate and the most legitimate Islamic authority on earth - but alJolani was willing to work more cooperatively with other militant groups. Like Abu Bakr, al-Jolani and al-Zawahiri aimed to build a caliphate eventually, but their strategy was much more protracted.

The Syrian civil war was the greatest political opportunity for jihadis since the Soviet invasion of Afghanistan in 1979. Yet ISIS and al-Qaida would not seize that opportunity together. Al-Zawahiri claimed that the Nusra Front was indeed independent of ISIS and, unsurprisingly, al-Jolani accepted that position. Abu Bakr rejected it, at which point open warfare erupted on the ground between the Nusra Front and ISIS. Entire military units switched sides overnight, sometimes killing their commanders in the process. It was a new phase in the Syrian civil war and the death knell for the long, uncomfortable accommodation between al-Qaida and the Zarqawist movement that had begun in Kandahar in 1999. ${ }^{71}$

\section{The Islamic State and the caliphate}

Despite their dispute, both ISIS and the Nusra Front initially thrived in Syria. As 2013 wore on, it became clear that the Syrian regime did not have the military strength to quickly suppress the rebellion, which remained a diverse hodgepodge of ideologies and groups. The Syrian war became a magnet for foreign fighters from abroad. 
In early 2007, more than 100 foreign fighters a month joined the ISI in Iraq, but that was nothing compared to the flow of foreigners entering Syria. ${ }^{72}$ Hundreds of fighters entered Syria every month, primarily through Turkey, which did little to stop the flow. Eventually, tens of thousands of people would join the fight in Syria from more than 80 countries, most of them joining either ISIS or the Nusra Front.

Some of the foreign groups were quite powerful. Central Asian jihadis arrived with years (even decades) of experience fighting Russia in the Caucasus and quickly became a center of military expertise for ISIS. When a group led by the veteran Chechen fighter Abu Omar al-Shishani defected from the Nusra Front to ISIS, it was a major coup for the more radical group.

In Syria, ISIS seized the city of Raqqa when fighters previously loyal to the Nusra Front defected. Raqqa became the symbol of ISIS territorial control and effectively served as the group's capital until 2017. In 2013, ISIS territorial gains in Syria drew most of the world's attention, but the group also reasserted control over major parts of Iraq. Ever since the U.S. troop surge destroyed the ISI's territorial holdings in Iraq, the group had worked silently and systematically to assassinate local governors and tribal leaders and rebuild networks across the country. That long-term effort started to pay off.

The heart of ISIS's project in Iraq was in Mosul, but the most dramatic early shifts occurred in Anbar Province. ISIS fighters seized neighborhoods in Fallujah and Ramadi, often with the help of local tribal officials fearful of the Shia-dominated government in Baghdad and the Iranian-sponsored militias that bolstered it. Iran had sponsored militias in Iraq since before the fall of Saddam, and they had played a major role attacking U.S. troops during the occupation. By 2013, those same networks were diverted to support the al-Assad government in Syria. When ISIS seized Raqqa in Syria and towns in Iraq's Anbar Province, they considered it all part of a single battle against a transnational Shia enemy.

Despite ISIS's dramatic growth and history in Iraq, the international community did not immediately recognize the threat. The perceived virtue of the Syrian rebellion colored assessments of anyone opposed to the Syrian regime, but this was bolstered by the erroneous belief that ISIS was less likely than al-Qaida to conduct attacks against the West. After all, al-Qaida explicitly prioritized attacks against the so-called "far enemy" - the West-and Zarqawists like ISIS focused on attacks against the "near enemy" of local governments.

This view was short sighted. The Zarqawists always aimed to confront the West eventually, and ISIS had strengthened so much that it could focus on local violence while still having capacity to invest in attacks abroad. Moreover, ISIS's focus on the "near enemy" was not nearly as absolute as some claimed. Dating back to 2008, the ISI's minister of war, al-Masri, claimed responsibility for a 2007 bomb plot in London. ${ }^{73}$ Indeed, ISIS's network outside of Iraq and Syria grew active in early 2014. In May, a French ISIS supporter opened fire at the Jewish Museum in Brussels. It was a hallmark of attacks to come. ${ }^{74}$

Before ISIS's international campaign gained full steam, the group continued to grow in Iraq and Syria. In early June 2014, ISIS fighters struck across Iraq. In Ramadi, they took over a local university, and in Baghdad, suicide car bombs detonated across the city. These attacks, however, were just a diversion for the real blow, which was coming farther north.

Mosul had been ISIS's stronghold in Iraq since the U.S. troop surge pushed the group out of Anbar Province in 2007. ISIS had deep underground networks, cooperative relationships with many politicians, and short supply lines to its rear base in Syria. Moreover, Mosul was a primarily Sunni city that was riven by disputes between Arab and Kurdish factions. It was far from Iraq's Shia population centers that provided most of the troops for the Iraqi army. Many soldiers felt they were defending a city that did not want them. Iraqi units in the city had been hollowed out by deserters and corrupt commanders who enlisted "ghost soldiers" that only existed to collect a salary that could be shared with officers. Official numbers suggested there were as many as 25,000 soldiers defending Mosul, but the actual number was closer to half that. ${ }^{75}$

ISIS began its attack by further undermining the defenders. It released propaganda claiming that its spies were everywhere in the city, including within the police and army; soldiers might fight, but they would never know whether the soldiers on either side of them were loyal. These messages were effective 
at undermining morale. When ISIS fighters entered Mosul in force, ISIS sleeper cells within the city rose up, confusing and terrifying the Iraqi army. Although ISIS only had a small number of fighters, the Iraqi defenses collapsed and soldiers scattered south. In a matter of days, a city of 1.8 million people had fallen into the hands of ISIS.

The offensive did not stop there. As Iraqi troops fled, ISIS fighters attacked in Fallujah and Ramadi and charged south from Mosul. Some observers even worried that Baghdad itself was in danger. ISIS's Mosul offensive shook the world out of its complacency. A terrorist group once left for dead now controlled major sections of both Syria and Iraq and was close enough to Baghdad to cause real concern. This was no longer a threat that could be wished away by the virtue of the broader Syrian revolution. ISIS was redrawing the borders of the Middle East.

ISIS had bigger aspirations than just Iraq and Syria. On June 29, 2014, Abu Muhammad al-Adnani, the group's spokesman, announced that the movement al-Zarqawi started a decade earlier was changing its name yet again. This announcement was different. Instead of simple nomenclature, al-Adnani announced that ISIS was declaring itself the caliphate, with global authority. Instead of limiting itself to "Iraq and alSham," the new entity would simply be called the "Islamic State." ${ }^{\prime 6}$ Abu Bakr al-Baghdadi, whom al-Qaida considered an unknown when he was announced as amir of the ISI in 2010, was named caliph. To punctuate the announcement, Abu Bakr led prayers at the Grand Mosque in Mosul on July 4, 2014. ${ }^{77}$

For its supporters, declaring the caliphate seemed to validate the group's propaganda and ideological disposition. Islamic State leaders had long claimed that their small, embattled group would one day rise to govern a new caliphate-and now they could point to that actually happening.

The Islamic State capitalized on this success to recruit even more. They appealed for people from all over the world to emigrate and join the caliphate, arguing that it was religiously required despite the risks. Islamic State propagandists also advanced a vision of impending apocalypse. They argued that reestablishing the caliphate was not simply a re-codification of jihadi power and authority, but it marked the beginning of a final eschatological battle between good and evil.

Apocalyptic rhetoric had been common in the Zarqawist movement since before the declaration of the ISI in 2006. It was a powerful motivational tool and allowed the group's leadership to imbue a sense of religious immediacy to their actions. For the Islamic State's leaders, it was not enough to support the concept of the Islamic State; would-be supporters urgently needed to take action because the end of the world was imminent. Their case was bolstered because Islamic prophecy suggested that apocalyptic battles would occur in northern Syria, precisely in the areas where its troops were engaged. ${ }^{78}$

The Islamic State's eschatological vision contrasted with its effort to build sustainable governing structures. If the end times were really evident, then establishing robust bureaucracies to pick up garbage and manage fisheries seemed strange. The concepts could be reconciled to the same violent ideological vision, but they suggested different resourcing priorities. Whatever Abu Bakr al-Baghdadi's true religious conviction, the group deftly used both its progress in governance and the specter of an apocalyptic fight to recruit and motivate supporters.

\section{The Islamic State targets the West, but falters in Iraq}

Even as Abu Bakr climbed the minbar (pulpit) in Mosul, the earliest signs of the Islamic State's future setbacks were already visible. Islamic State fighters who had rushed south toward Baghdad were stopped and shortly thereafter pushed back by a combination of Iraqi troops, Iranian-backed militias, and U.S. airpower. They had substantially overreached by pushing into the Iraqi heartland and would eventually pay the price.

By the standards of a jihadi terrorist group, the Islamic State was almost incomprehensibly powerful, but it thrived most when underestimated by its enemies. After the capture of Mosul, no one underestimated the Islamic State, and the results were predictable: it was slowly and steadily pushed back. 
The Islamic State's decline as a geographic entity began in late 2014, but it was a slow process. In the meantime, the Islamic State rebuilt a sophisticated governance structure modeled after the original framework announced in 2006. It established a leadership cadre; cabinet offices addressing everything from military affairs, immigrants, and health care; and federated authority to wilaya (provinces) in both Iraq and Syria and beyond. Over time, these sprouted globally, in regions as disparate as Libya, the Caucuses, Afghanistan, and the Philippines.

Functional wilaya replicated the overarching structure with governing bodies of their own, complete with distinct social service functions and propaganda distribution networks. This geographic and structural federation was necessary to manage the Islamic State's sprawling territory, but it also created resilience. The Islamic State could lose leadership and territorial control in a particular locale and still have functional organizations elsewhere in the world.

In the wake of declaring the caliphate, the Islamic State also announced its intention to conduct terrorist attacks around the globe. In September 2014, al-Adnani exhorted followers to attack in the West. "If you cannot find an [improvised explosive device] or a gun," he explained, "then find a disbelieving American or Frenchman . . . and smash his head with a rock or slaughter him with a knife." ${ }^{79}$ The Islamic State's predecessors had threatened Europe previously, and al-Zarqawi had conducted attacks outside Iraq and Syria, but this was the first time that an Islamic State leader put external attacks at the center of the group's political vision.

The core of the Islamic State's external operations fell within the Amniyat. This unit identified foreign fighters upon their arrival in Syria for specialized training and then sent them back to their home countries. It also engaged with supporters remotely and urged them to conduct simple attacks in their home countries. ${ }^{80}$

In 2015, the Amniyat campaign infrastructure started to emerge. In January, Belgian officials disrupted a large cell in the Belgian city of Verviers that hinted at an extensive operational capability in Europe. This network emerged in full force in the autumn, when the Islamic State bombed a Russian airliner flying out of the Egyptian resort town of Sharm el-Sheikh; bombed a Shia neighborhood in Beirut; and conducted a complex attack in Paris involving suicide attackers, small arms, and a hostage-taking operation at the Bataclan Theater. ${ }^{81}$

Moreover, the Islamic State catalyzed a distributed network of supporters to conduct attacks with little or no connection to the core organization that further advanced its overall goals. Al-Qaida had conducted attacks globally but did not generate a continuous campaign of violence like that produced by the Islamic State. None of the Islamic State's attacks approached the sophistication of 9/11, but a seemingly endless line of unsophisticated attacks threatened multicultural societies around the globe, especially in Europe.

The Islamic State's global reach sharpened the focus of political leaders around the world. Indeed, just before the Paris attacks, President Barack Obama announced that the Islamic State was losing territory in Iraq and Syria. The Iraqi army was slowly pushing north toward Mosul and retaking the major cities in Anbar Province. Key Islamic State provinces further afield were under pressure as well, especially in Libya, where the government and various Islamist militias routed Islamic State-linked groups.

Progress was slower in Syria despite Russia's intervention on behalf of the al-Assad regime and a more aggressive Western campaign against the Islamic State. Russia prioritized attacking militants that directly threatened the Syrian regime (which often did not include the Islamic State), and American intervention was limited to airstrikes and Special Operations Forces. Nonetheless, the basic strategic shift had occurred; the Islamic State was playing defense in Syria and Iraq while directing and inspiring terrorist attacks around the globe.

At times, the Islamic State made deeply counterproductive military decisions. Its enthusiastic charge toward Baghdad after capturing Mosul is a key example, but another was the 2015 campaign to capture the city of Kobane along the Syrian-Turkish border. The Islamic State tried for months to capture the city despite intense American air support for its defenders. The assault seemed suicidal to many, which led 
observers to speculate it was motivated in part by an Islamic prophecy that the final battle between good and evil would take place nearby. Whatever the motivation, the Islamic State's attack on Kobane was a military disaster.

The Islamic State was steadily rolled back in 2016 and 2017 despite a series of terrorist attacks abroad. The group had global reach, as it conducted attacks in Europe, the United States, North Africa, Central and South Asia, and in Southeast Asia. Some of the attacks involved fighters who had received direct training in Syria or Iraq and returned home, but other terrorists simply were inspired by the Islamic State's example and followed al-Adnani's exhortation to attack with a rock, knife, or car. ${ }^{82}$

Critically, the Islamic State emerged as the world's leading jihadi brand, which allowed it to attract fighters with a jihadi disposition but not a distinct position on the ideological and political divisions between al-Qaida and the Islamic State.

By mid-2017, the Islamic State was in serious decline. After a brutal siege, the Iraqi army retook Mosul, and Raqqa fell to U.S.-backed fighters. The number of foreign fighters entering Syria dropped precipitously, and many of the group's leaders were killed, including Abu Muhammad al-Adnani. The Islamic State was a shadow of its former self, but it would still fight on.

On October 26, 2019, the Islamic State faced another significant loss. Its longtime leader, Abu Bakr al-Baghdadi, was killed after he detonated a suicide vest during a U.S. Special Operations Forces military operation in Syria's Idlib Province. ${ }^{83}$

\section{Conclusion}

The decline of the Islamic State after its zenith in 2014 is reminiscent of the setbacks it faced in 2006 and 2007. Now, as then, the Islamic State faces tremendous military pressure in the areas it controls or once controlled, and it simply does not have the military capability to resist those forces conventionally.

Yet the imbalance today is not nearly as lopsided as it was in 2007 when 150,000 U.S. troops were concentrated against the ISI in Iraq. Indeed, the Islamic State today operates on an entirely different scale than the ISI did then. American commanders have suggested that the Islamic State has fighters measured in the low thousands, which is comparable to its reported numbers in early 2011. Today's Islamic State, however, also has a much broader set of affiliate organizations around the world and has many times more alumni who have fought in core combat zones and then drifted home or to other locations.

As the Islamic State suffers further military setbacks in Iraq and Syria, it is likely to adopt an operational approach similar to the ISI between 2008-2011. The group will probably shift to underground terrorist networks rather than an overt conventional force; focus on iterative large-scale terrorist attacks; and work to undermine the various forces arrayed against it via assassinations, bribery, and threats. The group will maintain a robust communications wing to sustain the commitment of true believers around the globe, and it will encourage supporters globally to continue to conduct terrorist attacks against civilian targets in Western countries.

This operational model is likely to be resilient for the Islamic State. Neither the Iraqi or Syrian government is well positioned to assert strong authority over their territories, which means that Islamic State cells will remain active. Indeed, Islamic State affiliates further afield will remain functional, as uprisings by supporters in Libya, Afghanistan, and the Philippines attest. None of these groups are likely to assert broad territorial control in the near term, but they represent a disruptive spoiler force in many places and a distinct terrorist threat.

The Islamic State's greatest advantages are the fractures among the coalition arrayed against it. In Iraq, Sunni tribal groups have once again rejected the Islamic State, but they are not necessarily supporters of the government in Baghdad or the Iranian-backed militias that support it. In Syria, the Russian-backed government, Western-backed rebels, and the Turkish government have all fought the Islamic State, but they eye each other warily. Governments around the Middle East agree that the Islamic State is a threat, 
but they continue their traditional geopolitical rivalries that threaten to distract from their focus against the group. Western governments are dedicated to defeating the Islamic State as well but are loath to maintain longstanding, semi-permanent military operations in the Middle East.

Nevertheless, the group is still a dangerous terrorist organization, and it will continue to threaten regimes in the Middle East and people all over the globe. It is hard to imagine that world leaders could ever underestimate the Islamic State after the tremendous damage it has done, but inattention helped the group rebuild underground after its setbacks in 2007. The Islamic State is a shadow of its former self, but it will wait, prepare, and hope for another political opportunity to emerge more forcefully again. The odds are against the Islamic State reasserting itself as a major territorial force, but there are no guarantees. After all, it has managed just such a resurrection act before.

\section{Notes}

1 Graeme Wood, "What ISIS Really Wants," The Atlantic, March 2015, www.theatlantic.com/magazine/ archive/2015/03/what-isis-really-wants/384980/.

2 Mary Anne Weaver, “The Short, Violent Life of Abu Musab al-Zarqawi," The Atlantic, June 8, 2006, www.theatlantic.com/magazine/archive/2006/07/the-short-violent-life-of-abu-musab-al-zarqawi/304983/; "Key Events in the Life of al-Zarqawi," New York Times, June 8, 2006, www.nytimes.com/2006/06/08/world/08timeline-zarqawi. html.

3 Ibid.

4 Ibid.

5 Joby Warrick, The Black Flags: The Rise of ISIS (New York: Doubleday, 2015).

6 Brian Fishman, The Master Plan: ISIS al-Qaeda and the Jihadi Strategy for Final Victory (New York: Yale University Press, 2016).

7 “Iraq: A Timeline of Abu Mus'ab al-Zarqawi," RFE/RL, June 9, 2006, www.rferl.org/a/1069045.html.

8 Weaver, "The Short, Violent Life of Abu Musab al-Zarqawi."

9 Ibid.

10 Ibid.

11 Fu'ad Husayn, “Al-Zarqawi: The Second Generation of al-Qa'ida,” al-Quds al-Arabi, May 13, 2005.

12 Warrick, The Black Flags.

13 Umar Abd al-Hakim (Abu Musab al-Suri), “The Global Islamic Resistance Call. Part I: The Roots, History, and Experiences," and "Part II: The Call, Program and Method," location and publisher unknown, December 2004.

14 Steven Brooke, "Strategic Fissures: The Near and Far Enemy Debate," in Self-Inflicted Wounds: Debates and Divisions within al-Qa'ida and its Periphery, ed. Assaf Moghadam and Brian Fishman (West Point: Combating Terrorism Center, 2010).

15 Ibid.

16 Ibid.

17 Ibid.

18 Daniel L. Byman and Jennifer R. Williams, ISIS vs. Al Qaeda: Jihadism's Global Civil War (Washington, DC: Brookings, 2015).

19 Mustafa Hamid and Leah Farrall, The Arabs at War in Afghanistan (London: Hurst Publishers, 2015$), 183$.

20 Byman and Williams, ISIS vs. Al Qaeda.

21 Hamid and Farrall, The Arabs at War in Afghanistan.

22 Muhammad al-Turayri, "Saudi al-Qaeda Member Relays His Experience of the 9/11 Attacks Alongside Bin Laden," al-Hayah, September 20, 2006.

23 Weaver, "The Short, Violent Life of Abu Musab al-Zarqawi."

24 Ibid.

25 Jeffrey Gettleman, “Zarqawi’s Journey: From Dropout to Prisoner to an Insurgent Leader in Iraq," New York Times, July 13, 2004, www.nytimes.com/2004/07/13/world/reach-war-profile-terror-zarqawi-s-journey-dropout-prisoner-insurgent-leader.html.

26 Karl Vick and Daniel Williams, “U.S. Strikes Alleged Al Qaeda Allies,” Washington Post, March 22, 2003 , www. washingtonpost.com/archive/politics/2003/03/22/us-strikes-alleged-al-qaeda-allies/5a2661d1-9b1a-4417-931ed9b0fc12c59e/.

27 Ibid.

28 Scheherezade Faramarzi, Iran's Salafi Jihadis (Washington, DC: Atlantic Council, 2018). 


\section{The history of the Islamic State}

29 Joby Warrick, “ISIS, With Gains in Iraq, Closes in on Founder Zarqawi’s Violent Vision,” Washington Post, June 14, 2014, www.washingtonpost.com/world/national-security/isiss-gains-in-iraq-fulfill-founders-violent-vision/2014 /06/14/921ff6d2-f3b5-11e3-914c-1fbd0614e2d4_story.html.

30 Samuel Helfont, Compulsion in Religion: Saddam Hussein, Islam, and the Roots of Insurgencies in Iraq (New York: Oxford University Press, 2018).

31 Amatzia Baram, Saddam Husayn and Islam, 1968-2003 (Washington, DC: Johns Hopkins University Press, 2014).

32 Dexter Filkins, "At Least 11 Die in Car Bombing at Jordan's Embassy in Baghdad," New York Times, August 7, 2003, www.nytimes.com/2003/08/07/international/worldspecial/at-least-11-die-in-car-bombing-at-jordans-embassy. html.

33 Dexter Filkins and Richard A. Oppel, Jr., “Top Aid Official Are Among 17 Killed,” New York Times, August 19, 2003, www.nytimes.com/2003/08/19/international/worldspecial/top-aid-officials-are-among-17-killed.html.

34 Bruce Riedel, Al Qaeda Strikes Back (Washington, DC: Brookings, 2010).

35 Vahid Brown, Cracks in the Foundation: Leadership Schisms in Al-Qa ida From 1989-2006 (West Point: Combating Terrorism Center, 2007).

36 Margaret Warner, “Marines Say New Fight for Fallujah Sparks Anguish Over Iraq War,” PBS News Hour, June 3, 2016, www.pbs.org/newshour/world/column-marines-say-latest-fight-for-fallujah-reignites-anguish-over-iraq-war.

37 Dexter Filkins, "Wanted Rebel Vows Loyalty to Bin Laden, Web Sites Say," New York Times, October 18, 2004, www.nytimes.com/2004/10/18/world/middleeast/wanted-rebel-vows-loyalty-to-bin-laden-web-sites-say.html.

38 "Letter from Tawhid w'al Jihad (Zarqawi Bayah)," Mu'askar al-Battar, October 17, 2004.

39 Dexter Filkins, "Iraq Videotape Shows the Decapitation of an American," New York Times, May 12, 2004, www. nytimes.com/2004/05/12/international/middleeast/iraq-videotape-shows-the-decapitation-of-an.html.

40 Fishman, The Master Plan.

41 “ISIS Rebels Declare 'Islamic State' in Iraq and Syria,” BBC, June 30, 2014, www.bbc.com/news/av/worldmiddle-east-28091637.

42 In July 2005, al-Qaida's second-in-command at the time, Ayman al-Zawahiri, wrote al-Zarqawi urging him to tone down the level of violence. "More than half of this battle is taking place in the battlefield of the media," al-Zawahiri wrote, urging al-Zarqawi to at least stop publicizing globally the atrocities he was committing in Iraq. For more, see "Zawahiri Letter to Zarqawi," July 9, 2005, https://fas.org/irp/news/2005/10/letter_in_english.pdf.

43 "Hotel Blasts Kill Dozens in Jordan," CNN, November 10, 2005, www.cnn.com/2005/WORLD/meast/11/09/ jordan.blasts/.

44 "Atiyah's Letter to Zarqawi," Combating Terrorism Center, no date, accessed November 15, 2020, https://ctc.usma. edu/harmony-program/atiyahs-letter-to-zarqawi-original-language-2/.

45 Brian Fishman, "The Man Who Could Have Stopped the Islamic State," Foreign Policy, November $23,2016$.

46 Ibid.

47 Robert F. Worth, "Blast Destroys Shrine in Iraq, Setting Off Sectarian Fury," New York Times, February 22, 2006, www.nytimes.com/2006/02/22/international/middleeast/blast-destroys-shrine-in-iraq-setting-off-sectarian.html.

48 Sean Naylor, Relentless Strike: The Secret History of Joint Special Operations Command (New York: St. Martin's Press, 2016), 279-289.

49 Ibid.

50 Fishman, "The Man Who Could Have Stopped the Islamic State."

51 Uthman bin Abd al-Rahman al-Tamimi, "Informing the People About the Islamic State of Iraq," Islamic State of Iraq Ministry of Sharia, 2007.

52 Haroro J. Ingram and Craig Whiteside, "Caliph Abu Unknown: Succession and Legitimacy in the Islamic State," War on the Rocks, November 25, 2019, https://warontherocks.com/2019/11/caliph-abu-unknown-successionand-legitimacy-in-the-islamic-state/.

53 Ibid.

54 Bill Roggio, Daveed Gartenstein-Ross, and Tony Badran, "Intercepted Letters Shed Light on State of Network in Iraq," Foundation for Defense of Democracies, September 12, 2008.

55 Dean Yates, "Senior al-Qaeda Figure in Iraq a Myth: U.S. Military," Reuters, July 18, 2007, www.reuters.com/ article/us-iraq-qaeda/senior-qaeda-figure-in-iraq-a-myth-u-s-military-idUSL1820065720070718.

56 "Al Qaeda Claims 12,000 Iraq Fighters," CBS, November 10, 2006, www.cbsnews.com/news/al-qaeda-claims12000-iraq-fighters/.

57 Jim Garamone, "Bombings Bear Signs of al-Qa'ida in Iraq, General Says," American Forces Press Service, August 15, 2011.

58 Brian Fishman, Redefining the Islamic State: The Fall and Rise of al-Qa'ida in Iraq (Washington, DC: New America, 2011).

59 William McCants, The Believer (Washington, DC: Brookings, 2015). 


\section{Brian Fishman}

60 Fishman, The Master Plan, 150-152.

61 "The Life and Death of Abu Bakr al Baghdadi," Wilson Center, October 28, 2019, www.wilsoncenter.org/article/ timeline-the-life-and-death-abu-bakr-al-baghdadi.

62 Brian Fishman, Redefining the Islamic State.

63 "Interview with Abu Ubaydah Abd al-Hakim al-Iraqi," Jihadist Media Elite and al-Furqan Media Establishment, April 11, 2011.

64 Rania Abouzeid, “The Jihad Next Door,” Politico, June 23, 2014, www.politico.com/magazine/story/2014/06/ al-qaeda-iraq-syria-108214.

65 "Announcing Jabhat al-Nusrah for the People of the Levant," al-Manarah al-Bayda Media Establishment, January 23, 2012.

66 The purpose of these prisoner releases is disputed. Some argue they were purely designed to strengthen extremist elements of the rebellion, but the first prisoner releases occurred even before violence had broken out writ large and were likely ill-advised attempts to placate the early revolutionary movement.

67 Jonathan Landay and Hannah Allam, "U.S. Might Name Syrian Rebel Nusra Front a Foreign Terrorist Group," McClatchy Newspapers, December 4, 2012, www.mcclatchydc.com/news/nation-world/world/article24741223. html.

68 Al-Sham generally refers to "Greater Syria," or the Levant. For the ISI's statement, see Abu Bakr al-Baghdadi, "Declaring the Establishment of the Islamic State of Iraq and al-Sham," al-Furqan Media Establishment, April 9, 2013.

69 Charles Lister, Profiling Jabhat al-Nusra (Washington, DC: Brookings, 2016), 5-13.

70 Ibid.

71 Ibid.

72 “The Rise, Spread, and Fall of the Islamic State," Wilson Center, October 28, 2019, www.wilsoncenter.org/article/ timeline-the-rise-spread-and-fall-the-islamic-state.

73 "Audio Interview with Abu Hamzah al-Muhajir, Minister of War of the Islamic State of Iraq," al-Furqan Media Establishment, October 24, 2008.

74 "Brussels Jewish Museum Murders: Mehdi Nemmouche Guilty," BBC, March 7, 2019, www.bbc.com/news/ world-europe-47490332.

75 Ned Parker, Isabel Coles, and Raheem Salman, "How Mosul Fell,” Reuters, October 14, 2014, www.reuters. com/article/us-mideast-crisis-gharawi-special-report/special-report-how-mosul-fell-an-iraqi-general-disputesbaghdads-story-idUSKCNOI30Z820141014.

76 Sylvia Westall, “AfterIraq Gains, Qaeda OffshootClaims Islamic 'Caliphate,'”Reuters, June 29, 2014, www.reuters.com/ article/us-syria-crisis-iraq/after-iraq-gains-qaeda-offshoot-claims-islamic-caliphate-idUSKBNOF40SL20140630.

77 Hannah Stranger, "Islamic State Leader Abu Bakr al-Baghdadi Addresses Muslims in Mosul," Telegraph, July 5, 2014, www.telegraph.co.uk/news/worldnews/middleeast/iraq/10948480/Islamic-State-leader-Abu-Bakr-al-Baghdadiaddresses-Muslims-in-Mosul.html.

78 For more on the Islamic State's apocalyptic vision, see William McCants, The ISIS Apocalypse (New York: St. Martin's Press, 2015). For criticism of the notion that the Islamic State's apocalyptic vision drove its original declaration of an Islamic state in 2006, see Fishman, The Master Plan.

79 Abu Muhammad al-Adnani, "Indeed Your Lord Is Ever Watchful," al-Furqan Media Establishment, September 22, 2014.

80 Jean-Charles Brisard and Kevin Jackson, “The Islamic State's Eternal Operations and the French-Belgian Nexus," CTC Sentinel 9, no. 11 (2016): 8-15.

81 Jason Hanna et al., "ISIS Publishes Photo of What It Says Is Bomb That Downed Russian Plane," CNN, November 19, 2015, www.cnn.com/2015/11/18/middleeast/metrojet-crash-dabiq-claim/index.html; "Paris Attacks: What Happened on the Night," BBC, December 9, 2015, www.bbc.com/news/world-europe-34818994.

82 Yara Bayoumy, “ISIS Urges More Attacks on Western 'Disbelievers'," Independent, September 23, 2014, www. independent.co.uk/news/world/middle-east/isis-urges-more-attacks-western-disbelievers-9749512.html.

83 Joby Warrick, “Abu Bakr al-Baghdadi, Extremist Leader of Islamic State, Dies at 48," Washington Post, October 27, 2019, www.washingtonpost.com/local/obituaries/abu-bakr-al-baghdadi-islamic-states-terrorist-in-chief-dies-at48/2019/10/27/0d004abc-663d-11e7-8eb5-cbccc2e7bfbf_story.html. 